\title{
A study on incidence of subclinical hypothyriodism in patients with heart failure
}

\author{
Sasthanathan. ${ }^{1 *}$, Prabhu G. ${ }^{2}$, Dhandapani. ${ }^{3}$ \\ DOI: https://doi.org/10.17511/ijmrr.2019.i03.02 \\ 1* Sasthanathan, Assistant Professor, Sri Venkateshwaraa Medical College Hospital \& Research Centre, Puducherry, India. \\ 2 G. Prabhu, Associate Professor, Sri Venkateshwaraa Medical College Hospital \& Research Centre, Puducherry, India. \\ 3 Dhandapani, Professor, Sri Venkateshwaraa Medical College Hospital \& Research Centre, Puducherry, India.
}

Objectives: Subclinical hypothyroidism $(\mathrm{SCH})$ is a common disorder that is characterized by elevated thyroid-stimulating hormone levels in conjunction with free thyroxine concentrations within the normal reference range. Thyroid hormones are known to affect the heart and vasculature and, as a result, the impact of $\mathrm{SCH}$ on heart failure. Strong evidence points to a link between SCH and HF risk factors such as alterations in blood pressure, lipid levels, and atherosclerosis. Additionally, accumulating evidence indicates that $\mathrm{SCH}$ is associated with metabolic syndrome and heart failure. The present review proposes that $\mathrm{SCH}$ may be a potentially modifiable risk factor of heart failure and mortality. Methods: This is an observational study to determine the incidence of subclinical hypothyroidism in patients with heart failure and the cardiovascular risk profile among patients in a 750 bedded tertiary health care centre in south India, over a period from June 2018 to November 2018. Results: In our present study it was noticed that most of the patients were in the age group above 51-60 yrs (45.45 \%). Our study data suggest that subclinical hypothyroidism with a TSH $\geq 10.0 \mathrm{mIU} / \mathrm{L}$ represents a potentially modifiable risk factor for HF in older adults but not subclinical hypothyroidism with moderate TSH levels (TSH 4.5 to $9.9 \mathrm{mIU} / \mathrm{L}$ ) and subclinical hyperthyroidism. Conclusion: Subclinical hypothyroidism are more prone to associated with heart failure as an asymptomatic which is essential to be identified and treated for a better outcome as its association is proven statistically in our study.

Keywords: Subclinical hypothyroidism, Heart failure, Hypothyroidism

\section{Corresponding Author}

Sasthanathan , Assistant Professor, Sri Venkateshwaraa Medical College Hospital \& Research Centre, Puducherry, India.

Email: dr.saastha@gmail.com

\section{How to Cite this Article}

Sasthanathan, Prabhu G, Dhandapani. A study on incidence of subclinical hypothyriodism in patients with heart failure. Int J Med Res Rev. 2019;7(3):157-161.

Available From

https://ijmrr.medresearch.in/index.php/ijmrr/article/ view/1052
To Browse

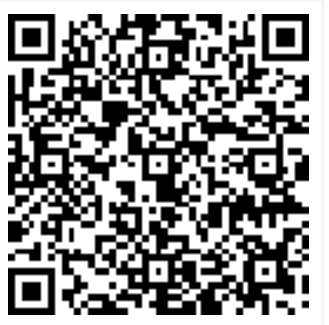

Manuscript Received 2019-04-25

Conflict of Interest No
Review Round 1 2019-05-04

Funding $\mathrm{Nil}$

Review Round 2
2019-05-10
$\begin{gathered}\text { Ethical Approval } \\ \text { Yes }\end{gathered}$

Review Round 2

Yes
Review Round 3

Plagiarism X-checker $6 \%$
Accepted 2019-05-14

Note

(c) 2019 by Sasthanathan, G. Prabhu, Dhandapani and Published by Siddharth Health Research and Social Welfare Society. This is an Open Access article licensed under a Creative Commons Attribution 4.0 International License https://creativecommons.org/licenses/by/4.0/ unported [CC BY 4.0]. 


\section{Introduction}

Hypothyroidism affects between $4 \%$ and $10 \%$ of the population, and the prevalence of subclinical hypothyroidism is reported to be as high as $10 \%$ in various studies [1-3]. Hypothyroidism is diagnosed when low levels of the thyroid hormones result in elevated levels of thyroid-stimulating hormone (TSH), whereas subclinical hypothyroidism is diagnosed when TSH levels are elevated above the upper limit of the assay reference range with normal thyroid hormone levels.

Thyroid hormones play an important role in the normal function of heart and vascular physiology, and hypothyroidism produces profound cardiovascular effects. Of recent clinical interest is the effect of subclinical hypothyroidism on cardiovascular disease and whether or not it should be treated. This review attempts to highlight the effects of hypothyroidism and subclinical hypothyroidism on the heart and current treatment strategies.

\section{Heart Failure and Hypothyroidism}

As described earlier, hypothyroidism can affect cardiac contractility, which is often diastolic in nature, and impair cardiac muscle relaxation. Associated diastolic hypertension and sometimescoexistent coronary artery disease further affect myocardial diastolic function [4].

Cardiac echocardiography has demonstrated impaired relaxation in patients with overt and subclinical hypothyroidism. In addition, early impaired relaxation has been demonstrated by prolongation of the isovolumetric relaxation time and reduction in the $E / A$ ratio in subclinical hypothyroidism $[5,6]$. The $E / A$ ratio are a ratio of early to late ventricular filling velocities, and a reduced $\mathrm{E} / \mathrm{A}$ ratio signifies diastolic dysfunction from impaired relaxation. Consequently, it results in a state of low cardiac output with decreased heart rate and stroke volume. It is well known that protein-rich Pericardial and/or pleural effusion often occur in hypothyroidism as a result of increased vascular permeability.

In advanced heart failure and shortly after myocardial infarction, the conversion of T4 to T3 decreases. Since T3 is the main regulator of gene expression in myocardial muscle, this decrease has been thought to affect myocardial contractility and remodeling [5].
Low free T3 levels also have been associated with increased mortality in patients with heart disease [7].

\section{Subclinical Hypothyroidism and the Heart}

Subclinical hypothyroidism is biochemically defined as a TSH level above the upper limit of the reference range with normal thyroid hormone levels. Severity of subclinical hypothyroidism is further defined based on the elevation in TSH levels, where mildly increased serum TSH levels range from $4 \mathrm{mIU} / \mathrm{L}$ to $10 \mathrm{mIU} / \mathrm{L}$, and anything above $10 \mathrm{mIU} / \mathrm{L}$ indicates severely increased TSH levels [4].

The reported prevalence of subclinical hypothyroidism depends on several factors, such as iodine supplementation, age, and race. In the United States, the prevalence of subclinical hypothyroidism is reported as $4.3 \%$ in the NHANES III study and as high as $9.5 \%$ in the Colorado study [8].

The annual risk of progression to overt hypothyroidism is reported at $1 \%$ to $5 \%$, depending on TSH levels and thyroid antibody status. Up to $60 \%$ of patients with subclinical Hypothyroidism can return to euthyroidism over 5 years, again based on TSH levels and antibody status. As described earlier, cardiovascular changes of arterial compliance, diastolic blood pressure, endothelial dysfunction, and hyperlipidemia that are noted with overt hypothyroidism can also occur in subclinical hypothyroidism [8].

In our study we focused the incidence of subclinical hypothyroidism in patients with heart failure and the cardiovascular risk profile among patients.

\section{Methodology}

Type of study and setting: This is an observational study to determine the incidence of subclinical hypothyroidism in patients with heart failure and the cardiovascular risk profile among patients in a 750 bedded tertiary health care centre in south India, over a period from June 2018 to November 2018.

Sampling method: 88 subjects were randomly selected among male and female healthcare provided among the above setting.

Sample collection: After written consent for enrollment in the study, a detailed history was taken from all the subjects along with a detailed clinical examination was obtained. 
Thyroid function test was performed on all the selected subjects after obtaining informed concern.

Inclusion criteria: Age $>30$ years and all patients admitted with Congestive heart failure.

Exclusion criteria: Age < 30 years, pregnant women and patients with past history of thyroid disorders and on treatment for the same.

Statistical method: The collected data was compiled and statistically analyzed.

\section{Results}

Table-1: Age \& sex wise distribution in heart failure patients.

\begin{tabular}{|l|l|l|l|l|}
\hline \multicolumn{1}{|c|}{ Age in years } & Male & Female & No. of patients & Percentage \\
\hline $40-50$ Years & 06 & 07 & 13 & 14.77 \\
\hline $51-60$ Years & 18 & 22 & 40 & 45.45 \\
\hline$>60$ Years & 17 & 18 & 35 & 39.77 \\
\hline Total & 41 & 47 & 88 & 100.0 \\
\hline
\end{tabular}

Totally 88 patients who presented with heart failure were included in this study. $14.77 \%$ of patients are in the age group of $40-50$ yrs. $45.45 \%$ of them are in the age group between 51-60yrs. About $39.77 \%$ of them were between in the age group of above $60 y$ rs.

There were no patients below the age group of below 40 years in the study. In the total 88 patients $41(46.59 \%)$ are males and $47(53.4 \%)$ of them are females. The Females are more in numbers compared to the males.

Table-2: Incidence of subclinical hypothyroidism in heart failure patients.

\begin{tabular}{|l|l|c|c|}
\hline \multicolumn{1}{|c|}{ Incidence } & \multicolumn{1}{|c|}{$\begin{array}{c}\text { No. of } \\
\text { patients }\end{array}$} & $(\%)$ & $\begin{array}{c}\text { P } \\
\text { value }\end{array}$ \\
\cline { 1 - 3 } $\begin{array}{l}\text { Heart failure with Subclinical } \\
\text { hypothyroidism }\end{array}$ & 34 & 38.63 & $\mathrm{P}<0.01$ \\
\cline { 1 - 3 } $\begin{array}{l}\text { Heart failure without Subclinical } \\
\text { hypothyroidism }\end{array}$ & 54 & 61.35 & \\
\cline { 1 - 4 } Total & 88 & 100.0 & \\
\hline
\end{tabular}

$38.63 \%$ of patients with heart failure are having Subclinical hypothyroidism among the 88 patients. The $p$ value is less than 0.01 , which is considered to be significant; this shows that the incidence of subclinical hypothyroidism is more in heart failure.

Table-3: Age specific prevalence of subclinical hypothyroidism in heart failure patients

\begin{tabular}{|l|l|l|l|l|}
\hline \multirow{2}{*}{ Age Group } & \multicolumn{2}{|c|}{ HF patients with SCH } & \multicolumn{2}{|c|}{ HF patients without SCH } \\
\cline { 2 - 5 } & No. $[\mathrm{n}=34]$ & Percentage & No. $[\mathrm{n}=54]$ & Percentage \\
\hline
\end{tabular}

\begin{tabular}{|l|l|l|l|l|}
\hline $40-50$ Years & 2 & 2.27 & 11 & 12.5 \\
\hline $51-60$ Years & 18 & 20.45 & 22 & 25 \\
\hline Above 60 Years & 14 & 15.9 & 21 & 23.86 \\
\hline
\end{tabular}

$2.27 \%$ of the patients in the age group of $40-50 \mathrm{yrs}$ are having subclinical hypothyroidism. $20.45 \%$ of patients in the age group of 51-60 yrs are having subclinical hypothyroidism. $15.9 \%$ of the patients in the age group of above 60 yrs are having subclinical hypothyroidism.

Table-4: Gender specific prevalence of subclinical hypothyroidism in heart failure patients

\begin{tabular}{|l|l|l|l|l|l|}
\hline \multirow{2}{*}{ Gender } & HF patients with SCH & \multicolumn{2}{|c|}{ HF patients without SCH } & \multirow{2}{*}{ P $<\mathbf{0 . 0 1}$} \\
\cline { 2 - 5 } & No of patients & $\%$ & No of patients & $\%$ & \\
\hline Male & 9 & 10.22 & 32 & 36.36 & \\
\hline Female & 25 & 28.4 & 22 & 25 & \\
\hline
\end{tabular}

$10.22 \%$ of males are having subclinical hypothyroidism, $28.4 \%$ of the females having subclinical hypothyroidism. The $p$ value is less than 0.01 which is considered to be significant. According to the study females are more commonly affected with subclinical hypothyroidism.

Table-5: BMI in subclinical hypothyroidism with heart failure

\begin{tabular}{|l|l|l|l|l|c|}
\hline \multirow{2}{*}{ BMI } & \multicolumn{2}{|c|}{$\begin{array}{c}\text { HF patients with } \\
\text { SCH }\end{array}$} & \multicolumn{2}{c|}{ HF patients without } & \\
\cline { 2 - 5 } & No of patients & $\%$ & No of patients & $\%$ & p $>0.0$ \\
\cline { 2 - 5 } \\
Normal weight [18- & 16 & 18.18 & 34 & 38.63 & 1 \\
\hline Overweight [23-25] & 6 & 6.81 & 13 & 14.77 \\
\hline Obese [>25] & 12 & 13.63 & 8 & 9.09 & \\
\hline
\end{tabular}

$18.18 \%$ of the patients with subclinical hypothyroidism are having normal weight. $6.81 \%$ of patients with subclinical hypothyroidism are overweight. $13.63 \%$ of patients with subclinical hypothyroidism are Obese $p$ value is $>0.01$ which is not significant.

Table-6: Prevalence of hypertension and diabetes mellitus in subclinical hypothyroidism with heart failure

\begin{tabular}{|l|l|l|l|l|l|}
\hline \multirow{2}{*}{ Risk factors } & HF patients with SCH & HF patients without SCH & p $>\mathbf{0 . 0 1}$ \\
\cline { 2 - 5 } & No of patients & $\%$ & No of patients & $\%$ \\
\hline Hypertension & 33 & 37.5 & 55 & 62.5 \\
\hline DM & 28 & 31.81 & 60 & 68.18 & \\
\hline
\end{tabular}

$37.5 \%$ of patients with subclinical hypothyroidism are having hypertension and $31.81 \%$ of patients are having diabetes mellitus. The $p$ value is more than 0.01 which is considered as not significant. 
Table-7: Age specific TSH levels in patients with subclinical hypothyroidism.

\begin{tabular}{|l|l|l|l|l|l|l|}
\hline \multirow{2}{*}{ TSH level } & \multicolumn{3}{|c|}{ Age } & \multirow{2}{*}{ Total } & \multirow{2}{*}{ p value } \\
\cline { 2 - 5 } & $40-50$ Years & $51-60$ Years & $>60$ Years & \multicolumn{2}{|c|}{} \\
\hline$<5.5$ & 07 & 28 & 19 & 54 & $61.36 \%$ & \\
\hline $5.51-10.0$ & 02 & 08 & 10 & 20 & $22.72 \%$ & $p<0.01$ \\
\hline Above 10.0 & 04 & 04 & 06 & 14 & $15.92 \%$ & \\
\hline Total & 13 & 40 & 35 & 88 & $100 \%$ & \\
\hline
\end{tabular}

$61.36 \%$ patients with subclinical hypothyroidism are having TSH level < 5.5. 22.72\% patients with subclinical hypothyroidism are having TSH level 5.510. $15.92 \%$ patients with subclinical hypothyroidism are having TSH level $>10$. $P$ value is less than 0.001 which is considered as significant.

\section{Discussion}

The thyroid is approximately 15 to $20 \mathrm{~g}$ in weight. Normal thyroid is made up of two lobes joined by a thin band of tissue, the isthmus. The individual lobes normally have a pointed superior pole and a poorly defined blunt inferior pole that merges medially with the isthmus. Blood supply is by the superior thyroid artery and the inferior thyroid artery. Thyroid blood flow ranges from 4 to 6 $\mathrm{mL} / \mathrm{min} / \mathrm{g}$. The gland is composed of follicles.Thyroid tissue appears as closely packed ring-shaped structures consisting of a single layer of thyroid cells surrounding a lumen. The follicular cells are columnar when active and cuboidal when inactive. The thyroid also contains parafollicular cells or $\mathrm{C}$ cells, that are the source of calcitonin.

There are approximately $250 \mu \mathrm{g}$ T4 per gram of net weight in normal human thyroid. This is sufficient to maintain a euthyroid state for at least 50 days. Thyroglobulin is present in the plasma of normal individuals at concentrations up to $80 \mathrm{ng} / \mathrm{mL}$. The first step in thyroid hormone release is the endocytosis of colloid from the follicular lumen by two processes: macro pinocytosis by pseudo pods formed at the apical membrane and micro pinocytosis by small coated vesicles that form at the apical surface.

Both processes are stimulated by TSH. Following endocytosis, endocytotic vesicles fuse with lysosomes, and proteolysis is catalyzed by cathepsin $\mathrm{D}$ and D-Iike thiol proteases, all of which are active at the acidic $\mathrm{pH}$ of the lysosome. The iodotyrosines released from $\mathrm{Tg}$ are rapidly deiodinated by an NADPH-dependent iodotyrosine deiodinase, and the released iodine is recycled.
The thyroid hormone transporter MCT8 in the thyroid gland could be involved in the exit of $\mathrm{T} 4$ and or T3 from the phagolysosome or thyroid cell.

Stimulation of DI- and D2- (type 1 and 2 deiodinases) can catalyze 5 '-deiodination of T4.T4 release from the thyroid cells is inhibited by several agents, the most important of which is iodide.

The analysis included a study group containing 88 patients of Heart Failure who were admitted in Sri Venkateshwaraa medical college Hospital and research centre. The analysis of age group in Heart Failure patients showed that the youngest patient was 40 years and the oldest was 74 years. In our present study it was noticed that most of the patients were in the age group above 51-60 years [45.45\%].

In a similar study shows the majority of patients admitted to hospital are aged over 60, with $25 \%$ aged between 60 and 74 and $68 \%$ over the age of 75 [9]. Another study conducted by Llyold-Jones DM et al showed that the prevalence of heart failure increases with the age from less than $1 \%$ in the 20 $39 \mathrm{yr}$ old age group to over 20 percent in the people aged $80 \mathrm{yr}$ or older.

The analysis of study sex distribution showed that the male patients are having Heart failure of $46.59 \%$ and female patients with $53.4 \%$ which was study conducted by Stromberg $A$ et al., In this study, it was observed that $34(38.63 \%)$ of the patients with Heart failure are having subclinical hypothyroidism which is found to be significant, Rodondi et al., in his study also proves that subclinical hypothyroidism patients had almost double the risk of developing heart failure.

In a study conducted by Nanchen $D$ et al patients with low or very high TSH along with normal free T4 are at increased risk of incipient heart failure. In this study, it was observed that male $9(10.22 \%)$ and female $25(28.4 \%)$ are affected by subclinical hypothyroidism. Subclinical hypothyroidism is highly prevalent in elderly women. A prevalence of $11-26$ $\%$ had been reported in previous studies, $[10,13]$. our study shows a prevalence of $24 \%$ in concordance with the other studies.

Surveys that stratified TSH levels indicate a predominance of $\mathrm{TSH}<10 \mathrm{mIU} / \mathrm{L}$, which accounts for about $55-85 \%$ of cases. $[11,14]$ In our study almost $22.72 \%$ of our patients with subclinical hypothyroidism had TSH levels $<10 \mathrm{mIU} / \mathrm{L}$. 
In our present study, it is observed that BMI in subclinical hypothyroidism does not differ and also supported by previous study by La Rue A et al [15]. The initial Whickham study observed that lipid levels were not associated with TSH elevation after age adjustment [12]. In our present study data suggest that subclinical hypothyroidism with a TSH $\geq 10.0$ $\mathrm{mIU} / \mathrm{L}$ represents a potentially modifiable risk factor for HF in older adults but not subclinical hypothyroidism with moderate TSH levels [TSH 4.5 to $9.9 \mathrm{mIU} / \mathrm{L}$ ] and subclinical hyperthyroidism. The results of the present study demonstrate that abnormal LV diastolic filling (suggestive of impaired LV relaxation) is a common finding in patients with Subclinical hypothyroidism.

\section{Conclusion}

Subclinical hypothyroidism is more prone to associated with heart failure as an asymptomatic which is essential to be identified and treated for a better outcome as its association is proven statistically in our study. Subclinical hypothyroidism is highly prevalent in heart failure as an independent co factor in women $>$ men associated with heart failure. Our study gives the platform to access the thyroid function test in all the patients with heart failure to identify $\mathrm{SCH}$ which has its importance in outcome if treated promptly.

Abbreviation: $\mathrm{SCH}$ - Subclinical Hypothyroidism

\section{Reference}

01. Klein I, Danzi S. Thyroid disease and the heart. Circulation. 2007 Oct 9;116(15)1725-35.

[Crossref]

02. Ochs N, Auer R, Bauer DC, et al. Meta-analysissubclinical thyroid dysfunction and the risk for coronary heart disease and mortality. Ann Intern Med. 2008 Jun 3;148(11)832-45. [Crossref]

03. Razvi S, Shakoor A, Vanderpump M, et al. The influence of age on the relationship between subclinical hypothyroidism and ischemic heart disease- a metaanalysis. J Clin Endocrinol Metab. 2008 Aug;93(8)2998-3007.

doi: 10.1210/jc.2008-0167 [Crossref]

04. Pearce SH, Brabant G, Duntas LH, et al. 2013 ETA Guideline: Management of Subclinical Hypot hyroidism. Eur Thyroid J. 2013;2(4):215-28.

doi: 10.1159/000356507. [Crossref]
05. Kahaly GJ, Dillmann WH. Thyroid hormone action in the heart. Endocr Rev. 2005 Aug;26(5)704-28.

DOI: 10.1210/er.2003-0033 [Crossref]

06. Rodondi N, Bauer DC, Cappola AR, et al. Subclinical thyroid dysfunction, cardiac function, and the risk of heart failure- The Cardiovascular Health study. J Am Coll Cardiol. 2008 Sep 30;52(14)1152-9. doi: $10.1016 /$ j.jacc.2008.07.009 [Crossref]

07. Iervasi G, Pingitore A, Landi $P$, et al. Low-T3 syndrome- a strong prognostic predictor of death in patients with heart disease. Circulation. 2003 Feb $11 ; 107(5) 708-13$.

[Crossref]

08. Cooper DS, Biondi B. Subclinical thyroid disease. Lancet. 2012 Mar 24;379(9821)1142-54.

doi: $\quad 10.1016 / S 0140-6736(11) 60276-6$ [Crossref]

09. Bastenie PA, Vanhaelst L, Neve P. Coronaryartery disease in hypothyroidism. Lancet. 1967 Dec 9;2(7528)1221-2.

[Crossref]

10. Pittman JA Jr, Dailey GE 3rd, Beschi RJ. Changi ng normal values for thyroidal radioiodine upta ke. N Engl J Med. 1969 Jun 26;280(26)1431-4.

DOI: $10.1056 /$ NEJM196906262802602 [Crossref]

11. Bastenie PA, Banhaelst L, Bonny $M$, Neve $P$, Staquet M. 1971- Preclincal hypothyroidism a risk factor for coronary heart disease. Lancet. $1 ; 203-204$.

[Crossref]

12. Zondek AJ. Kamilton EA. Heart and hypothyroidism. Arch Intern Med. 1918;53-65 [Crossref]

13. Wang R, Nelson JC, Weiss RM, et al. Accuracy of free thyroxine measurements across natural ranges of thyroxine binding to serum proteins. Thyroid. 2000 Jan;10(1)31-9.

DOI: $10.1089 /$ thy.2000.10.31 [Crossref]

14. Monzani F, Caraccio N, Del Guerra P, Casolaro A, Ferrannini E. 1999 Neuromuscular symptoms and dysfunction in subclinical hypothyroid patients- beneficial effect of L-T4 replacement therapy. Clin Endocrinol. 51;237-242.

[Crossref] 
15. Kahaly GJ. Cardiovascular and atherogenic aspects of subclinical hypothyroidism. Thyroid. 2000 Aug;10(8)665-79.

DOI: $\quad 10.1089 / 10507250050137743 \quad$ [Crossref] 